\title{
Review of the southern hemisphere fish family Chironemidae (Perciformes: Cirrhitoidei)
}

\author{
Revisión de los peces de la familia Chironemidae (Perciformes: Cirrhitoidei) del Hemisferio Sur
}

\section{Roberto Meléndez ${ }^{1}$ and Brian S. Dyer ${ }^{2}$}

\author{
${ }^{1}$ Universidad Andres Bello, Facultad de Ecología y Recursos Naturales, Biología Marina, Avda. República 440, Santiago, \\ Chile.rmelendez@unab.cl \\ ${ }^{2}$ Escuela de Recursos Naturales, Universidad del Mar, Angamos 680, Reñaca, Viña del Mar, Chile
}

\begin{abstract}
Resumen.- La familia Chironemidae comprende peces costeros que se distribuyen solamente en el Océano Pacífico Sur, frente a las costas de Australia, Nueva Zelanda, las islas Lord Howe, Kermadec y Norfolk, y las islas oceánicas frente a Chile central (Archipiélago de Juan Fernández) y por el norte (islas San Félix y San Ambrosio). La literatura reciente ubica a las especies de Chironemidae en dos géneros: Chironemus con cinco especies y el monotípico Threpterius maculosus. Este trabajo presenta una revisión de Chironemidae y propone sinonimizar Threpterius con Chironemus, sobre la base de filogenias moleculares y morfológicas. La familia Chironemidae se compone por: Chironemus bicornis (Chile), C. delfini (Chile), C. georgianus (Australia), C. marmoratus (Australia y Nueva Zelanda), C. microlepis (Islas Lord Howe, Kermadec, Norfolk y Poor Knights) y Chironemus maculosus (Australia y Nueva Zelanda). Se designa un neotipo de Chironemus delfini. Se entrega una clave artificial para las especies.
\end{abstract}

Palabras clave: Chironemus, Threpterius, Chile, Australia, Nueva Zelanda

\begin{abstract}
Chironemidae are marine coastal fishes distributed only in the southern Pacific Ocean, off Australia, New Zealand, Lord Howe Island, Kermadec Island, Norfolk Island and the oceanic islands off northern (San Félix and San Ambrosio Islands) and central Chile (J uan Fernández Archipelago). Recent literature place Chironemidae species in two genera: Chironemus with five species and the monotypic Threpterius maculosus. This paper reviews the Chironemidae and proposes the synonymy of Threpterius with Chironemus based on the molecular and morphological phylogenies. The family Chironemidae was composed of Chironemus bicornis (Chile), C. delfini (Chile), C. georgianus (Australia), C. marmoratus (Australia and New Zealand), C. microlepis (Lord Howe Island, Kermadec Island, Norfolk Islands and Poor Knights Island) and Chironemus maculosus (Australia and New Zealand). A neotype of Chironemus delfini is designated. An artificial key to species is provided.
\end{abstract}

Key words: Chironemus, Threpterius, Chile, Australia, New Zealand

\section{INTRODUCTION}

The family Chironemidae currently comprises two genera, Chironemus and Threpterius (Last et al. 1983, Paulin et al. 1989, Nelson 2006, Burridge et al. 2006, Eschmeyer 2009). Chironemus is composed of five species: $C$. bicornis (Steindachner, 1898) and C. delfini (Porter, 1914), both distributed around archipelagos off north-central Chile, and C. georgianus (Cuvier, 1829), C. marmoratus (Günther, 1860) and C. microlepis (Waite, 1916) variably distributed in the southern Australia and New Zealand (Fig. 1). Threpterius is considered monotypic, with T. maculosus Richardson, 1850 distributed only in southern Australia and New Zealand area.

Gill (1862) defined the Chironematinae as fishes with ..."teeth acutely conical and small. Dorsal fin with its spinous portion generally more or less longer than the soft, with thirteen to fifteen spines, the membrane behind each of which is deeply and acutely notched. Ventral fin generally obtuse and rounded. Caudal fin truncated or subtruncated."... He synonymized the genus Threpterius with Chironemus but also stated that "...Threpterius may be re-established...”, although indicating that the cirrhitiform percoids might be refer to as a single family Cirrhitidae with five subfamilies, including the Cheilodactylinae. Regan (1911:260) proposed a relation-ship between the five families, Aplodactylidae, Cheilodactylidae, Chironemidae, Cirrhitidae and Latridae, suggesting that they be placed in Order Cirrhitiformes.

Greenwood (1995) recognised five families within the suborder Cirrhitoidei based mainly on the shape of the urohyal. Even though he did not include the genus 
Threpterius in his analysis, he presented evidence for extracting the monotypic genus from the Chironemidae. Based on a phylogenetic study he inferred familial status on certain cirrhitoid genera and concluded that Chironemidae is the sister group of a trichotomy composing the Latridae, Aplodactylidae and Cheilodactylidae, with the Cirrhitidae as the sister group of the four family assemblage.

Nelson (2006) restricted the distribution of the Chironemidae to the Australia-New Zealand area. Meléndez (1990), however, indicated a wider distribution that includes the southeastern Pacific, extending to the oceanic islands off northern (Desventuradas Islands: San Félix and San Ambrosio, ca., $26^{\circ} \mathrm{S}, 78^{\circ} \mathrm{W}$ ) and central Chile (Juan Fernández Archipelago: Robinson Crusoe and Alejandro Selkirk Islands, $c a .33^{\circ} \mathrm{S}, 79^{\circ} \mathrm{W}$ ). The same geographical range in the southeast was indicated by Pequeño \& Sáez (2000), Pequeño \& Lamilla (2000) and Burridge et al. (2006)

Burridge et al. (2006), presented three phylogenetic analyses of Chironemidae: one based on morphology, in which Threpterius is paraphyletic with Chironemus; one based on DNA indicating that Threpterius is included in a monophyletic Chironemus, and a combined morphological and molecular phylogenetic analysis in which Chironemus, including Threpterius is also monophyletic.

The purpose of this paper is to present a review of the family Chironemidae and a key to its species.

\section{Material ANd Methods}

A total of 135 specimens of Chironemidae were examined. Museum acronyms are according to Leviton et al. (1985), except for IIOA (Instituto de Investigaciones Oceanológicas, Antofagasta, Chile). Counts and measurements are based on Hubbs \& Lagler (1954). Counts included: scales on lateral line (SLL), scales above lateral line (SALL), scales below lateral line (SBLL). In pectoral fin counts, the total number is given first and, in parenthesis, roman numbers correspond to digitiform rays and arabic numbers to rays. For the osteological analysis, specimens of all species of Chironemus and Threpterius were cleared and stained following Taylor \& Van Dyke (1985). Dissection of specimens follows Weitzman (1974) with modifications. The standard length is abbreviated as SL.

\section{TAXONOMY}

Family Chironemidae Gill

Genus Chironemus Cuvier, 1829

Diagnosis: Body slender. Some adults with a variously sized "hump" in the postcephalic-predorsal area. Membrane between spines of the dorsal fin varying from slightly notched to deeply notched, with 0 to 22 cirri on the tip of the dorsal-fin spines. Scales present or absent on membranes between rays of dorsal and anal fins. Dentary with a patch of teeth at the symphysis or in a row. Body scales variable in size. Interorbital space mostly concave to flat. Ventral fins abdominal. Dorsal fin with 13

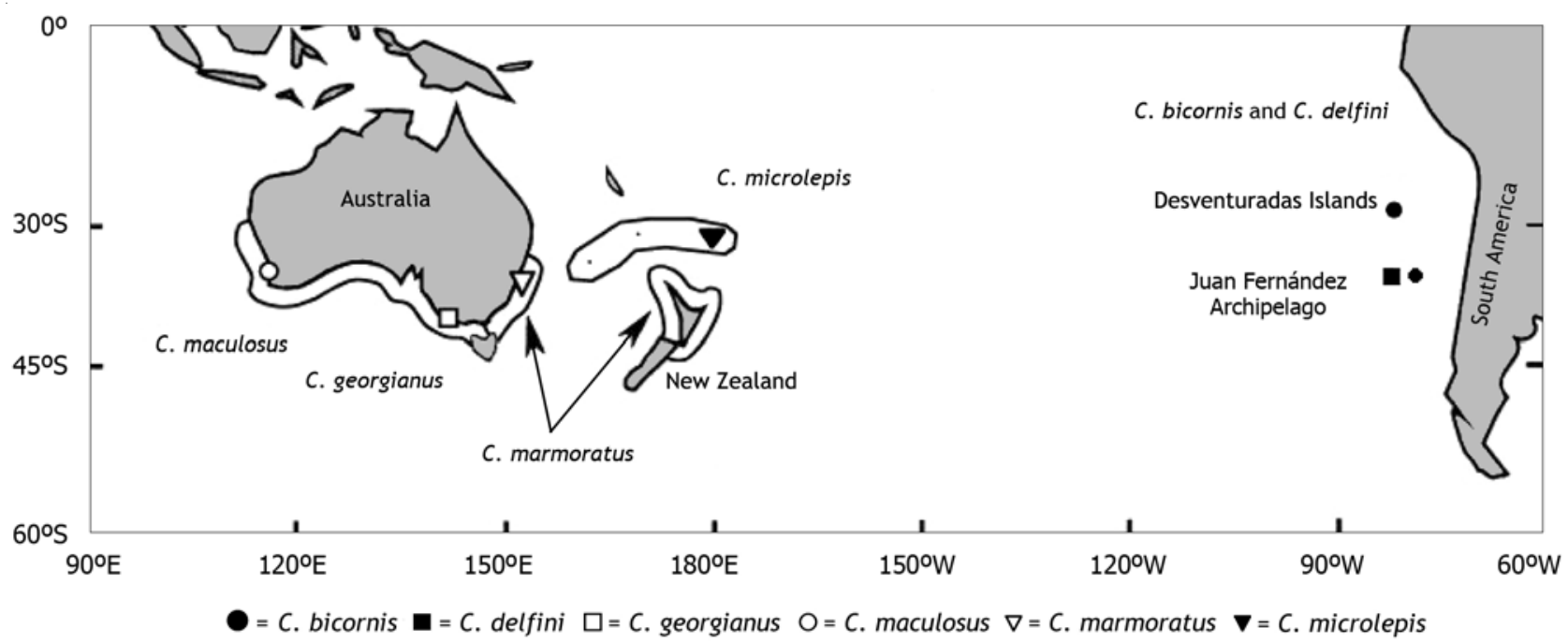

Figure 1. Species distribution map of the genus Chironemus (modified from Burridge et al. 2006) / Mapa de la distribución de especies del género Chironemus (modificado de Burridge et al. 2006) 


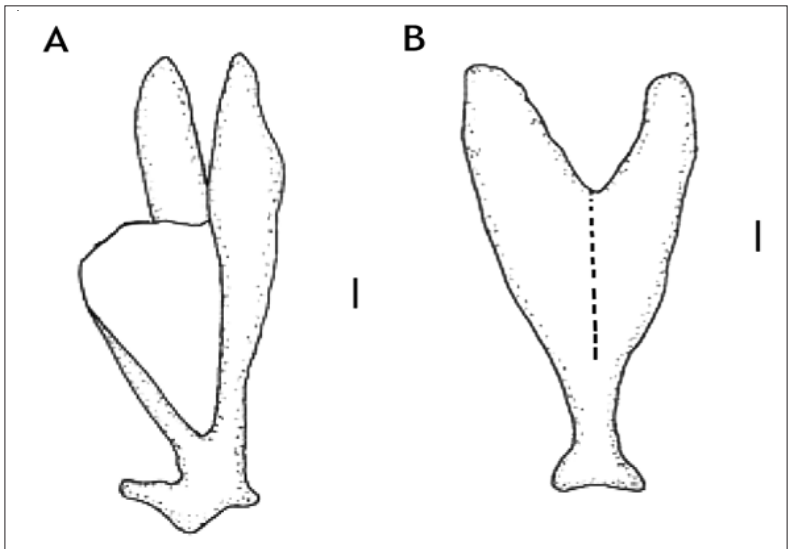

Figure 2. Urohyal bone of Chironemus maculosus. A: lateral view, B: ventral view / Hueso urohial de Chironemus maculosus. A: vista lateral, B: vista ventral

to 16 spines and 15 to 19 rays. Anal fin with six to eight rays. Base of anal fin 9.9-18.7 \% SL. Preorbital length 5.8$13.7 \%$ SL. Urohyal bone shallow (depth/length proportion 22) (chironemid type of Greenwood 1995), or with posteroventral alar expansions longer than the main body of the bone (Fig. 2 A, B).

Table 1. Number of dorsal fin rays ( D1) in Chironemus species / Número de radios en la aleta dorsal (D1) de las especies de Chironemus

\begin{tabular}{lccccccc}
\hline D1 & 14 & 15 & 16 & 17 & 18 & 19 & 20 \\
\hline C. bicornis & & & & 20 & 17 & 1 & \\
C. delfini & & 11 & 6 & & & & \\
C. georgiamus & 1 & 3 & 19 & 4 & & & \\
C. maculosus & & & & 5 & 10 & 2 & \\
C. marmoratus & & & & 1 & 8 & 9 & 1 \\
C. microlepis & & & & 8 & 7 & & \\
\hline
\end{tabular}

Numbers of dorsal fin rays and modified scales on the lateral line in Chironemus species are presented in Tables 1 and 2.

\section{Key to THE SPECIES OF CHIRONEMUS (ADULTS OVER 120 MM SL)}

$1 \mathrm{a}$. Scales present at the membranes between rays of dorsal and anal fins. Membrane between dorsal-fin spines with a shallow notch. Upper lips thick and fleshy. Base of anal fin $9.9-14.7 \%$ SL. Preorbital length 7.4-13.7\% SL 2

$1 \mathrm{~b}$. Scales absent at the membranes between rays of dorsal and anal fins. Membrane between dorsal-fin spines deeply notched. Upper lips not thick and fleshy. Base of anal fin 15.7-18.7\% SL. Preorbital length 5.8-7.2\% SL

C. maculosus

2 a. More than 10 cirri at the tip of each dorsal fin spine. 3

$2 \mathrm{~b}$. Less than five or no cirri at the tip of each dorsal fin spine 4

3 a. Less than 54 scales in the lateral line. One of the upper pectoral digitiform rays greatly produced ......C. georgianus

3 b. More than 54 scales in the lateral line. None of the upper pectoral digitiform rays very produced..... C. delfini

4 a. More than 68 scales in lateral line C. microlepis

$4 \mathrm{~b}$. Less than 68 scales in lateral line 5

5 a. A prominent bone projection dorsocaudally on the orbit. 62-65 modified scales in lateral line. C. bicornis

5 b. No prominent bone projection dorsocaudally on the orbit. 56-61 modified scales in the lateral line.

C. marmoratus

Table 2. Number of scales in lateral line (LL) of Chironemus species / Número de escamas sobre la línea lateral (LL) de las especies de Chironemus

\begin{tabular}{|c|c|c|c|c|c|c|c|c|c|c|c|c|c|c|c|c|c|c|c|c|c|c|c|c|c|c|c|c|}
\hline LL & 48 & 49 & 50 & 51 & 52 & 53 & 54 & 55 & 56 & 57 & 58 & 59 & 60 & 61 & 62 & 63 & 64 & 65 & 66 & 67 & 68 & 69 & 70 & 71 & 72 & 73 & 74 & 75 \\
\hline C. bicornis & & & & & & & & & & & & & & & 3 & 6 & 7 & 2 & & & & & & & & & & \\
\hline C. delfini & & & & & & & & & & & & 1 & 10 & 5 & 2 & & & & & & & & & & & & & \\
\hline C. georgiamus & 1 & & 7 & 4 & 9 & 5 & & & & & & & & & & & & & & & & & & & & & & \\
\hline C. maculosus & & & & & & & & 1 & 1 & & 1 & 5 & 5 & 1 & 3 & & & & & & & & & & & & & \\
\hline C. marmoratus & & & & & & & & & 2 & & 8 & 2 & 3 & 4 & & & & & & & & & & & & & & \\
\hline C. microlepis & & & & & & & & & & & & & & & & & & & & & & & 1 & 1 & 4 & 4 & 2 & 2 \\
\hline
\end{tabular}




\section{SPECIES ACCOUNT}

Chironemus bicornis (Steindachner, 1898). Fig. 3.

Chilodactylus bicornis Steindachner, 1898:291.

Cheilodactylus bicornis: Delfin 1901:71, Mann 1950:34, Mann 1954:45, De Buen 1959:136, Bahamonde \& Pequeño 1975:14, Sepúlveda 1987:241, Pequeño 1989:63.

Chironemus bicornis: Steindachner 1905:205, Meléndez 1990:87, Meléndez \& Villalba 1992:12, Pequeño \& Sáez 2000:32, Pequeño \& Lamilla 2000:437.

Chilodactylus bicornis: Quijada 1913:30, Porter 1914:22, Rendahl 1921:50.

Chirodactylus bicornis: Fowler 1945:93, Fowler 1951:307.

Chilodactylus delfini (non Porter) De Buen 1959:136.

Type material: Chironemus bicornis: ZMB 15630 Syntypes (2) (not found at ZMB).

Material examined: CAS $5569(1 ; 53,5), \operatorname{MCZ} 46175(1 ; 43)$, MNHNC P. 6202 (4; 113,1-159), MNHNC P. 6207 (1; 190), MNHNC P. 7221 (2 + 2 c\&s; 151,7-177,2), SIO 65-636 (16; 25,3-148), SIO 65-657 (10; 27,3-172), SIO-65-636 (1; 148), USNM 227305 (1; 39,3). X-ray plate: MCZ 51018(2).

Diagnosis: A species of Chironemus with a well developed frontal bone projection on its upper posterior edge. The maxilla does not reach the anterior edge of the orbit. Interorbital space strongly concave. Maximum length recorded $250 \mathrm{~mm}$ SL.

Description: Body slender, elongate, low. Small head, 29.0$32.9 \%$ SL, preorbital length $8.7-11.8 \%$ SL, with a well developed frontal bone projection on the upper posterior edge, orbital diameter 6.7-8.8\% SL. Interorbital width 6.48.4\% SL. Maxilla not reaching anterior edge of orbit, 7.69.6\% SL. Dentary with a patch of teeth. Predorsal length 27.2-31.7\% SL. Base of dorsal fin 58.2-66.2\% SL. Base of spinous portion of dorsal fin 32.8-36.3\% SL. Base of soft portion of dorsal fin 26.7-33.8\% SL. Ratio between base of soft dorsal fin and base of spinous dorsal fin equal or greater than 0.75 (range: 0.75-1.1). Preanus length 57.9$58.6 \%$ SL. Preanal fin length 66.0-72.6\% SL. Anal fin base 9.9-12.3\% SL. Maximum pectoral fin length 27.7-31.1\% SL. Maximum body depth 21.6-27.5\% SL. Minimum height of caudal peduncle 8.4-9.6\% SL. Scaly sheath present at base of the dorsal and anal fins. Mostly without cirri at tip of dorsal fin spines, sometimes one or two present. Fifth spine of dorsal fin longest. Second spine of anal fin longest. Pectoral fin not reaching anal fin. No pectoral ray notably longer than the rest. White spot dorsally on opercle. No scales on dorsal and anal fin membranes. Chest scales anterior to pelvic fin, small and very imbricated. Scales on rest of body at least twice as large as scales chest. Anterior nostril with two large lobes, both with numerous cirri.

Dorsal fin XIII - XIV, 17-19. Anal fin III, 6-8. Pectoral fin 15 (VI - 9). Anal fin III, 6-8. SLL 62-64, SALL 12, SBLL 14-15.

Colour in life: Most of body yellowish brown. Ventral region is more yellow than rest of body. Nasal and cheek areas with yellowish spots. Preopercular area below orbit yellowish. Eyes with golden iris. Upper corner of opercle with a white spot. Dorsal part of body above lateral line, with seven short brown stripes that continue toward dorsal fin, but do not reach lateral midline of body. Three short brown stripes in middle of body followed by another three towards caudal peduncle, below lateral line. Often stripes oriented horizontally and bars vertically. Pectoral, pelvic, anal and caudal fins with yellowish spots and dark brown stripes. Dorsal fin with yellowish spots, upper margin black.

Colour in alcohol: Ventral region dusty white. Seven short brownish stripes on light brown body. Often stripes oriented horizontally and bars or bands vertically. All fins with whitish spots, except the spinous portion of the dorsal fin.

Distribution: This species is distributed in the Juan

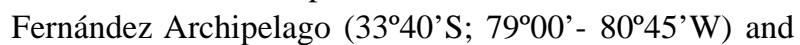
Desventuradas Islands (San Félix and San Ambrosio)

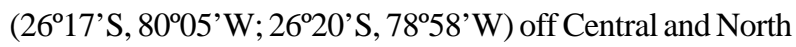
of Chile, respectively, at depths of 1 to $20 \mathrm{~m}$ (Meléndez 1990, Pequeño \& Sáez 2000, Dyer \& Westneat 2010) (Fig. 1).

Comparison: This species is very similar morphologically to $C$. microlepis, but it differs mainly in having a very well developed bone projection above the orbit. It differs from other Chironemus species in having 0 - 4 cirri at the tip of the dorsal-fin spines.

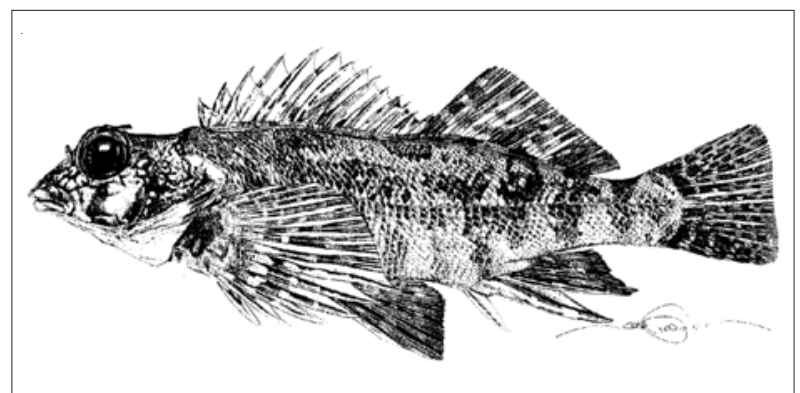

Figure 3. Chironemus bicornis (MNHNC P. uncatalogued. 159 mm SL) / Chironemus bicornis (MNHNC P. no catalogado. $159 \mathrm{~mm}$ LS) 
Chironemus delfini (Porter, 1914). Fig. 4.

Chilodactylus delfini Porter, 1914:22.

Chironemus delfini: Meléndez 1990:85, Meléndez \& Villalba 1992:12, Pequeño 1997:83, Pequeño \& Sáez 2000:32, Pequeño \& Lamilla 2000:437.

Type material: Chironemus delfini: MNHNC P 6654 (1; 385) neotype.

Material examined: FMNH 107340 (1), FMNH 107341 (1), IIOA 0999 (2; 236,5-359,5), MCZ 46157 (2; 51-53), MNHNC P 6655 (1; 175), MNHNC P 6656 (1; 260), MNHNC P 6772 (4, 215-250 + 2 c\&s), SIO 65-655 (3; 174-245), USNM 88769 (1; 315). X-ray plate: SIO 65-655 (3).

Diagnosis: A species of Chironemus with a long maxilla reaching at least the middle of the orbit. Interorbital space flat. Ratio between lengths of the base of the soft dorsal fin and the base of the spinous dorsal fin less than 0.75 (range: 0.48-0.65). Maximum length about $400 \mathrm{~mm}$ SL.

Description: Body slender, moderately high, especially larger specimens. Head large, 34.0-40.3\% SL. Preorbital length 9.6-13.7\% SL. Orbit diameter 5.4-6.7\% SL. Interorbital width 5.3-6.8\% SL. Maxilla reaching middle of orbit, 10.9$15.9 \%$ SL. Dentary with a patch of teeth. Predorsal length 28.5-38.2\% SL. Base of dorsal fin 56.9-66.9\% SL. Base of spinous portion of dorsal fin 35.5-44.9\% SL. Base of soft portion of dorsal fin 20.2-24.8\% SL. Ratio between base of soft dorsal fin and base of spinous dorsal fin, less than 0.75 (range: $0.48-0.65$ ). Preanus length $64.3-71.7 \%$ SL. Preanal fin length $66.3-75.3 \%$ SL. Anal fin base 11.0-14.4\% SL. Maximum pectoral fin length 27.8-30.9 \% SL. Maximum body depth 24.4-38.9\% SL. Minimum height of caudal peduncle 10.1-11.5\% SL. More than five cirri present at tip of each dorsal-fin spine. Third and fourth spine of dorsal fin the longest. Second anal fin spine the longest. Chest scales anterior to pelvic fin, small and imbricated. Scales on rest of body at least twice as large as scales chest. Anterior nostril with two large lobes, both with numerous cirri.

Dorsal fin XV, 15 - 16. Anal fin III, 6- 8. Pectoral fin 15 (VII8). Anal fin III, 6-8. SLL 59-62. SALL 8-9. SBLL 12-14.

Colour in life: Body reddish brown with small whitish spots all over the body, including fins. A red spot on the upper opercle. Region behind the head and above lateral line with eight short black stripes anteriorly and three stripes posteriorly, some of them reaching the ventral midline at the level of the origin of the anal fin. All fins darker than the body.
Colour in alcohol: Some specimens with body totally greyish to dark brown, with weak small white spots. Other specimens with yellowish body, whitish spots and eight diffuse small brown stripes.

Distribution: Chironemus delfini is endemic to the Juan Fernández Archipelago, at depths from 5 to $30 \mathrm{~m}$ (Meléndez 1990, Pequeño \& Sáez 2000, Dyer \& Westneat 2010) (Fig. 1).

Comparison: This species resembles $C$. georgianus mainly in the relative lengths of the soft and spinous dorsal fin bases, the number of dorsal fin rays (Table 1), and in the number of cirri at the tip of the dorsal fin spines (more than five). The last feature distinguishes $C$. delfini from $C$. marmoratus, C.bicornis, C. microlepis and C. maculosus. Chironemus delfini is distinguished from C. georgianus which has a maxilla that does not reach the middle of the orbit .

Remarks: Although described in 1914 by the Chilean naturalist Carlos Porter, this species long remained unknown to ichthyologists (e.g., Fowler 1945, Bahamonde \& Pequeño 1975, Pequeño 1989 and Sepúlveda 1987) except De Buen (1959), who regarded it as a junior synonym of C. bicornis. Chilean ichthyologists followed either Fowler (1945) or De Buen (1959), until Meléndez (1990) redescribed and resurrected the species.

In his original description, Porter did not indicate where the type specimen was deposited. As Porter was working at the Museo de Historia Natural de Valparaíso, Chile, we believe the type specimen was deposited there. A couple of years after the description was published a fire completely destroyed the Museum and all fish specimens were lost, we have therefore selected specimen MNHNC P. 6654 as neotype of Chironemus delfini.

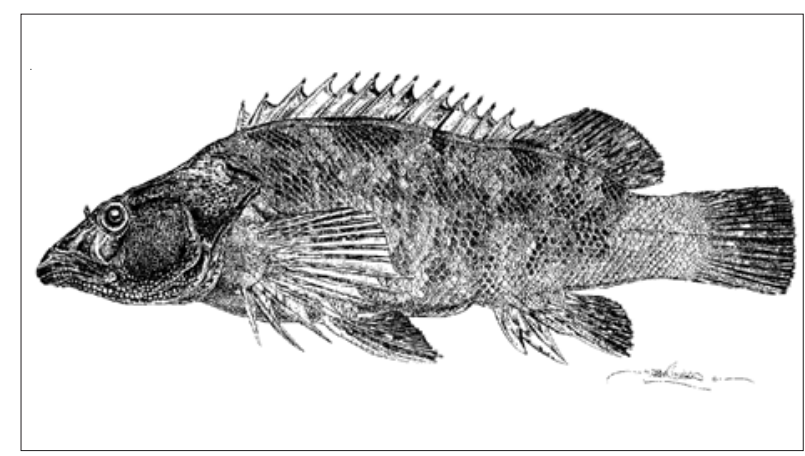

Figure 4. Chironemus delfini (MNHNC P. 6654. $385 \mathrm{~mm} \mathrm{SL}$, neotype) / Chironemus delfini (MNHNC P. 6654. 385 mm LS, neotipo) 


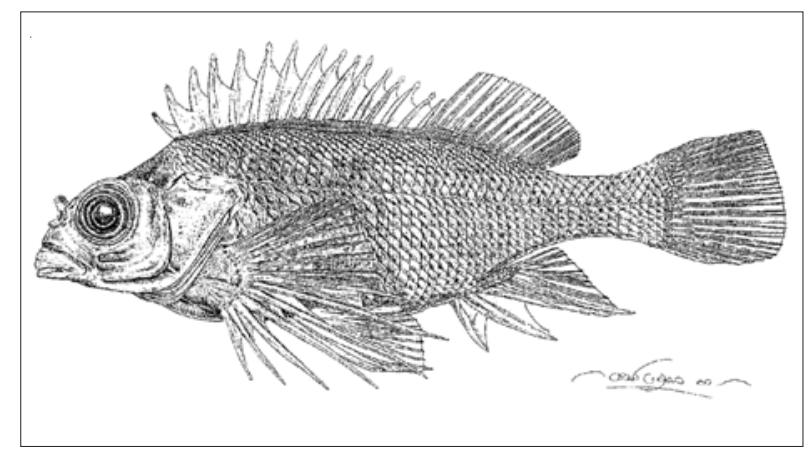

Figure 5. Chironemus georgianus (WAM 26007-001. $127 \mathrm{~mm}$ SL) / Chironemus georgianus (WAM 26007-001. 127 mm LS)

Chironemus georgianus Cuvier, 1829. Fig. 5.

Chironemus georgianus Cuvier, 1829: 78.

Chironemus georgianus: Gill 1863:11. Last et al. 1983:391. Bauchot \& Desoutter 1989:11, Kuiter 1993:254. Gomon et al. 1994:639.

Threpterius chalceus: Scott 1954:108. Glover 1976:173. Gomon et al. 2008:621.

Type material: Chironemus georgianus: MNHN A-3818 Holotype (not in good shape, seen on digital photograph)

Material examined: AMS I.20162-001 (6; 62,1-148,9), AMS 16980010 (1; 134), AMS 19629026 (1; 101), NMV-A2525 (1; 48,2), WAM-P26007-003 (1; 126,4), WAM P.27127-014 (8; 45-105), WAM-P27129-011 (3; 51,1-91,8), WAM-P27644005 (5; 68-107,8) (2 c\&s), WAM-P28285-009 (1; 66).

Diagnosis: A species of Chironemus with less than 54 scales in the lateral line. Maxilla reaching the anterior edge of the orbit. Interorbital space flat. A scaly sheath covering the base of the spinous and soft dorsal fins. The second digitiform ray of the pectoral fin greatly produced. Maximum length reaching 200 mm SL (Gomon et al. 1994).

Description: Body short, relatively high, slightly compressed laterally. Head 33.5-38.7\% SL. Preorbital length 9.3-11.7\% SL. Orbit diameter 8.3-10.2\% SL. Interorbital width 7.1-8.5\% SL. Maxilla reaching anterior edge of the orbit, 8.3-11.0\% SL. Dentary with a patch of teeth. Predorsal length 27.1-31.6\% SL. Base of dorsal fin 58.4-65.4\% SL. Base of spinous portion of dorsal fin 35.1-41.4\% SL. Base of soft portion of dorsal fin 21.8-24.6\% SL. Ratio between lengths of base of soft dorsal fin and the base of the spinous dorsal fin equal or less than 0.75 (range: 0.560.75). Preanus length 57.2-67.7\% SL. Preanal fin length
62.6-74.0\% SL. Anal fin base 10.8-13.3\% SL. Maximum pectoral fin length 32.7-38.7\% SL. Maximum body depth 29.5-36.0\% SL. Minimum height of the caudal peduncle 9.0-10.2\% SL. Anterior nostril with two large lobes both with numerous cirri. Tips of dorsal fin spines mostly with 16 to 19 cirri. Seventh and eighth spine of the dorsal fin the longest. Second spine of anal fin longest. Largest pectoral fin ray almost reaches origin of anal fin and longer than pelvic fin. Chest scales anterior to pelvic fin, small and very imbricated. Scales on rest of body at least twice as large as scales chest. A white spot on the upper anterior corner of the opercle.

Dorsal fin XV-XVI, 14-17. Anal fin III, 6-7. Pectoral fin 1415 (VI-VII, 7- 9). Anal fin III, 6-7. SLL 48-53. SALL 6-8. SBLL 9-12.

Colour in life: Body grey to brown, darker above. Small, silver spot at upper tip of opercle. Fins with dark banded rays (Gomon et al. 1994).

Colour in alcohol: Body completely light brown to dark golden, with six dark brown short stripes. All fins with a dark brown reticulate pattern.

Distribution: This species has been found only in southern Australia, from Wilson Promontory (Victoria) to Perth (western Australia), including Tasmania, inhabiting shallow waters to about $10 \mathrm{~m}$ depth (Gomon et al. 1994) (Fig. 1).

Comparison: This species resembles C. delfini, mainly in having a similar number of cirri on the membrane of the spinous dorsal fin, but differs in having a shorter maxilla. Differs from other species of Chironemus in having fewer scales above the lateral line (Table 2). This species reaches the smallest maximun size of all Chironemus species.

Chironemus maculosus (Richardson, 1850). Fig. 6.

Threpterius maculosus Richardson, 1850: 70.

Threpterius maculosus: Last et al. 1983:392. Paulin et al. 1989:200. Herman et al. 1990:3. Kuiter 1993: 255. Gomon et al. 1994:641.

Chironemus maculosus: Günther 1860: 78, Gill 1863:114. Gomon et al. 2008:622

Type material: Threpterius maculosus: NMSZ 1980.073.004 Syntype (1, dry skin) (not seen).

Material examined: AMS 13166 (1; 210), AMS 16980-012 (1; 165), AMS 19629-023 (2; 122-147), AMS 20162-002 (1; 191), AMS 20166-009 (1; 220), AMS 20171-024 (1; 258), 
AMS 20189-006 (4; 177-214), NMNZ P 22131 (1; 273), WAM-P24844 (1; 135,5), WAM-P25767-005 (2; 85-83), WAM-P27956-012 (1; 182,3), WAM-P28280-009 (1; 80,7). X-ray plate: NMNZ P 33231 (1)

Diagnosis: Body slender, with a "hump" in the postcephalic-predorsal area. A scaly sheath on the soft portion of the dorsal fin. Tip of the dorsal fin spines with 19 to 22 cirri. No thick fleshy lips. Interorbital space flat to slightly convex. Soft dorsal fin area and anal fin bases with a scaly sheath. One row of teeth on the dentary. Scales covering body of about the same size as scales on chest. Membrane between dorsal fin spines deeply notched. Base of anal fin 15.7-18.7\% SL. Preorbital length 5.8-7.2\% SL. Urohyal bone similar to chironemid type of Greenwood (1995), but with posteroventral alar expansions longer than the main body of the bone (Fig. 2 a,b). Maximum length reaching $330 \mathrm{~mm}$ SL (Gomon et al. 1994).

Description: Body deep, with a pronounced hump immediately behind head. Head length $29.4-33.7 \%$ SL. Preorbital length short, 5.8-7.2\% SL. Orbit diameter 6.710.7. Interorbital width $4.4-5.3 \%$ SL. Maxilla reaching posterior edge of orbit, 10.0-12.9\% SL. One row of teeth on the dentary. Predorsal length 22.9-28.4\% SL. Base of dorsal fin $67.0-72.8 \%$ SL. Base of spinous portion of dorsal fin 34.7-38.9\% SL. Base of soft portion of dorsal fin 29.5$36.3 \%$ SL. Ratio between lengths base of soft dorsal fin and base of spinous dorsal fin greater than 0.75 (range: 0.79-0.98). Preanus length 54.7-65.0\% SL. Preanal fin length $59.8-66.6 \%$ SL. Anal fin base 15.7-18.7\% SL. Maximum pectoral fin length 25.1-34.6\% SL. Maximum body depth 30.6-41.0\% SL. Minimun height of caudal peduncle 9.5$11.2 \%$ SL. A scaly sheath on the soft portion of the dorsal fin. Anterior nostril with upper lobe well developed and with numerous cirri. Fifth or sixth spines of dorsal fin longest. Second spine of anal fin longest. Small scales on dorsal and anal fins.

Dorsal fin XIV, 17-19. Anal fin III, 7-9. Pectoral fin 14-15 (VII-VIII, 7-8). Anal fin III, 6-7. SLL 55-62. SALL 7-10. SBLL 13-16.

Colour in life: Body grey-white to brown-red, with darker blotches, bright silver spot on upper, pointed, free edge of each opercle (Gomon et al. 1994).

Colour in alcohol: Body light brown with some short and diffuse dark stripes. Upper margin of the opercle with a white spot. Most of the fins with a series of whitish and brownish bands.

Distribution: This species is found only in the southern Australia and New Zealand. In Australia from Lancelin (Western Australia) to the Bass Strait coast of Victoria and Tasmania, in shallow waters to $10 \mathrm{~m}$ depth (Gomon et al. 1994) (Fig. 1).

Comparison: This is a very distinctive species, differing morphologically from other Chironemus species, in having a predorsal hump, larger scales on the chest, thin lips, a scaly sheath on the soft portion of the dorsal fin, and one row of teeth on the dentary.

Relationships: Gill (1862) regarded Threpterius as a junior synonym of Chironemus, but stated that Threpterius might be re-established. He did not examine any specimens of either genera. Subsequently, Regan (1911) recognized the family Chironemidae, which included Chironemus and Threpterius based on, among other characters, the number of spines and rays in the dorsal and anal fins, the form of teeth in jaws and vomer, no subocular shelf, and very short occipital crest. A phylogenetic study of chironemid relationships by Burridge et al. (2006) stated that morphological data supported a paraphyletic Threpterius relationship with Chironemus, whereas molecular and morphological data combined supported the hypothesis that T. maculosus is included in Chironemus. As a result we regarded Threpterius as a junior synonym of Chironemus.

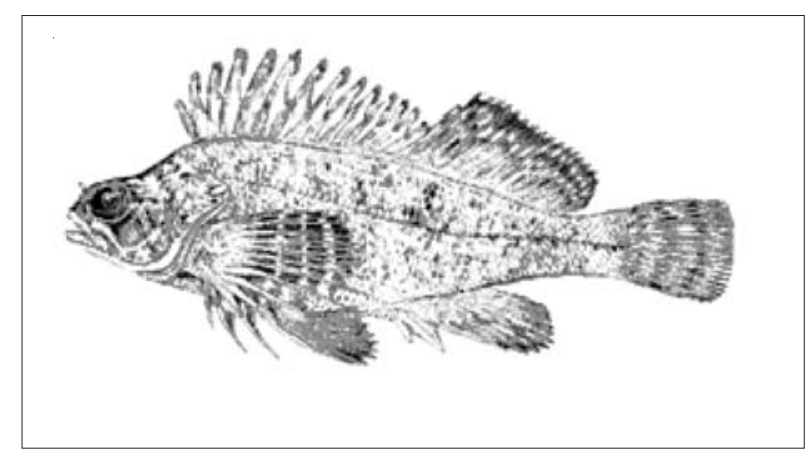

Figure 6. Chironemus maculosus (WAM 27956-012. $183 \mathrm{~mm}$ SL) / Chironemus maculosus (WAM 27956-012. 183 mm LS) 


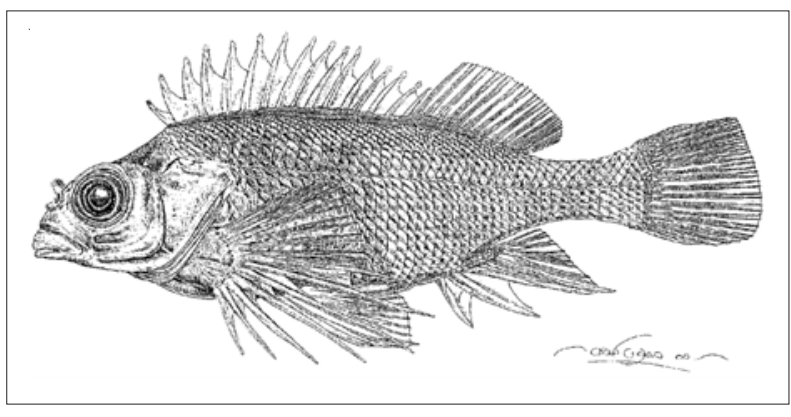

Figure 7. Chironemus marmoratus (NMV A2185. 258 mm SL) / Chironemus marmoratus (NMV A2185. 258 mm LS)

Chironemus marmoratus Günther, 1860. Fig. 7.

Chironemus marmoratus Günther, 1860: 76

Chironemus marmoratus: Gill 1862:114. Roughley 1916:121. Doak 1972:64. Last et al. 1983:391. Paulin et al. 1989: 200. Francis 1993:164. Kuiter 1993:255. Gomon et al. 1994:640. Greenwood 1995:2. Gomon et al. 2008:622

Chironemus aboriginalis: Ogilby 1893:54. Whitley 1931:321.

Haplodactylus fergussoni Hector 1875: 243.

Type material: Chironemus marmoratus: BMNH Syntypes: (2 skins) (not seen).

Material examined: NMNZ 2000 (1; 310), NMNZ P 2723 (1; 235), NMNZ 3095 (1; 259), NMNZ P 3282 (1; 58,2), NMNZ 4664 (1; 272), NMNZ P 5529 (1; 204), NMNZ P 5548 (1; 225), NMNZ 8132 (1; 288), NMNZ P 10451 (1; 96,4), NMNZ 21584 (2; 225-245), NMNZ 21589 (1; 230), NMNZ 21604 (1; 215), NMNZ 21672 (1; 222), NMNZ P $21784(1 ; 102,3)$ (1c\&s), NMNZ P 26468 (1; 244), NMNZ P 27959 (2; 176205) (1c\&s), NMNZ P 29988 (1; 89,3), NMNZ P 33399 (1; 208,6), NMV-A20532 (2; 167-180,3), NMV-A2185 (1; 258), SIO 78-236 (2; 84,6-201), WAM P 27074-009 (1; 152), WAM P 29128-001 (2; 75-91,2). X-ray plates: NMNZ P 81 (1), NMNZ P 287 (1), NMNZ P 1619 (1), NMNZ P 2000 (1), NMNZ P 2723 (1), NMNZ P 3095 (8), NMNZ P. 3282 (1), NMNZ P 3410 (7), NMNZ P 4664 (1), NMNZ P 5529 (2), NMNZ P 5548 (1), NMNZ P 5651 (1), NMNZ P. 6622 (2), NMNZ P 8132 (1), NMNZ P 10451 (1), NMNZ P. 10452 (3), NMNZ P 13277 (1), NMNZ P 14417 (4), NMNZ P 15081 (2), NMNZ P 18375 (1), , NMNZ P 20594 (1), NMNZ P 21584 (1), NMNZ P 21589 (1), NMNZ P 21604 (1), NMNZ P 21636 (3), NMNZ P 21672 (1), NMNZ P 21784 (15), NMNZ P 26468 (1), NMNZ P. 27959 (2), NMNZ P 29988 (1), NMNZ P 33399 (1), SIO 78-236(5),
Diagnosis: A species of Chironemus with maxilla not reaching the anterior edge of the orbit. Interorbital space moderately concave. Presence of a slight knob on the upper posterior edge of the frontal bone. Maximum length of 400 mm SL (Gomon et al. 1994).

Description: Body slender, elongate, relatively low. Head 30.5-34.4\% SL. Preorbital length 10.5-12.7\% SL. Orbit diameter $6.0-8.4 \%$ SL. Interorbital width 5.8-7.9\% SL. Maxilla barely reaching anterior edge of orbit $8.3-10.6 \%$ SL. Dentary with a patch of teeth. Predorsal length 27.4$31.8 \%$ SL. Base of dorsal fin 59.1-65.9\% SL. Base of spinous portion of dorsal fin 29.6-36.8\% SL. Base of soft portion of dorsal fin 28.1-32.9\% SL. Ratio between the lengths of base of soft dorsal fin and base of spinous dorsal fin greater than 0.75 (range: $0.8-1.1$ ). Preanus length $58.3-65.5 \%$ SL. Preanal fin length $64.2-72.1 \%$ SL. Anal fin base 10.2$14.6 \%$ SL. Maximum pectoral fin length 27.8-36.4\% SL. Maximum body depth 26.1-32.0\% SL. Minimum height of caudal peduncle 9.1-11.4\% SL. Fifth and sixth dorsal-fin spine longest. One cirrus on tip of dorsal fin spine. Anterior nostril with two large lobes both with numerous cirri. First digitiform pectoral ray longest, not quite reaching tip of pelvic fin. Second and third anal fin spines about same length.

Dorsal fin XIV, 17-20. Anal fin III, 6-7. Pectoral fin 14-16 (VI-VII, 8-9). Anal fin III, 6-7. SLL 58-61. SALL 9-12. SBLL 10-15.

Colour in life: Body light grey, greenish, pinkish or brownish, peppered with tiny bright white or yellow spots, which are larger on fins (Gomon et al. 1994).

Colour in alcohol: Body dark brown to golden light with six short stripes. Head with moderate reticulation pattern.

Distribution: Chironemus marmoratus is distributed in the littoral zone of south-eastern Australia. It has been found also in Lord Howe Island and New Zealand. In Australia from southern Queensland to northern Tasmania and eastern Victoria, in shallow waters to $10 \mathrm{~m}$ depth (Gomon et al. 1994) (Fig. 1).

Comparisons: This species is similar to $C$. bicornis and $C$. microlepis mainly in having a bony projection on the upper posterior edge of the orbit, which in C. marmoratus is slightly developed. It differs from C. microlepis in the fewer number of scales in the lateral line $(<65)$ (Table 2). 


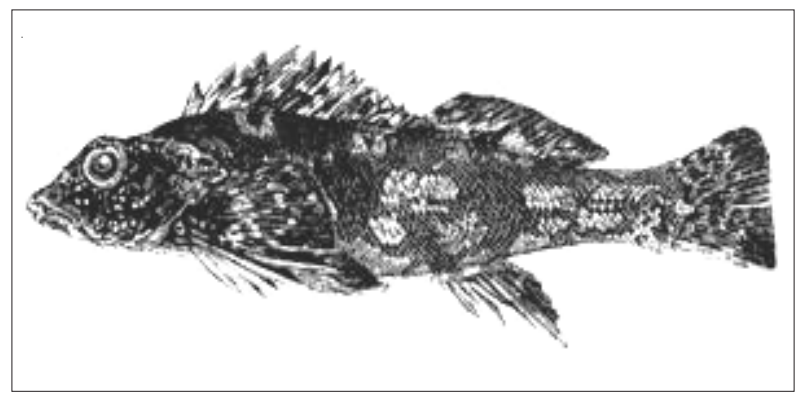

Figure 8. Chironemus microlepis (NMNZ P 17844. $250 \mathrm{~mm} \mathrm{SL}$ ) / Chironemus microlepis (NMNZ P 17844. 250 mm LS)

Chironemus microlepis Waite, 1916. Fig. 8.

Chironemus microlepis Waite, 1916:456.

Chironemus microlepis: Paulin et al. 1989: 200, Francis 1993:164.

Type material: Chironemus microlepis: AMS I.5411 Holotype (not seen).

Material examined: AMS I 14067 (1; 275), NMNZ P 13455 (1; 192,7), NMNZ P 13518 (1; 147,7), NMNZ P 17506 (1; 223), NMNZ P 17844 (1; 248), NMNZ P 20001 (5; 27,3144,3) (1 c\&s), NMNZ P 20009 (1; 135,6), NMNZ P 20010 (3; 60,6-67), NMNZ P 20012 (1; 150,9). X-ray plate: NMNZ P. 13494 (2), NMNZ P 13518 (1), NMNZ P 17506 (1), NMNZ P 17844 (1), NMNZ P 20001 (5), NMNZ P 20009 (5), NMNZ P. 20010 (3), NMNZ P 20012 (1), NMNZ P 134455 (1).

Diagnosis: A species of Chironemus with more than 68 scales on the lateral line. With a moderate frontal bone projection on the upper posterior edge. Maxilla not reaching the anterior edge of the orbit. Interorbital space concave. Maximum size about $330 \mathrm{~mm}$ SL.

Description: Body elongate and low. Head short 28.7-32.7\% SL. Preorbital length 10.1-12.1\% SL. Orbit diameter 5.98.1\% SL. Interorbital width 6.3-8.2\% SL. Maxilla short, 8.6$10.6 \%$ SL. Dentary with a patch of teeth. Predorsal length 27.3-31.8\% SL. Base of dorsal fin 59.8-64.5\% SL. Base of spinous portion of dorsal fin 31.8-36.1\% SL. Base of soft portion of dorsal fin 28.1-30.9\% SL. Ratio between the lengths of base of soft dorsal fin and base of spinous dorsal fin greater than 0.75 (range: 0.78-0.95). Preanus length 57.6-63.1\% SL. Preanal fin length 64.8-69.8\% SL. Anal fin base 10.1-12.6\% SL. Maximum pectoral fin length 23.6-31.4\% SL. Maximum body depth 22.8-26.0\% SL. Minimum height of caudal peduncle 8.7-9.9\% SL. Mostly without cirri on tip of dorsal fin spine. Chest scales anterior to pelvic fin, small and very imbricated. Scales on rest of body at least twice as large as scales chest. Anterior nostril with two large lobes, both with numerous cirri. Fourth and fifth dorsal fin spines longer. Third anal fin spine longest.

Dorsal fin XIV-XV, 17-18. Anal fin III, 6-7. Pectoral fin 14-15 (VI, 8- 9). Anal fin III, 6-7. SLL 70-75. SALL 9-12. SBLL 1521.

Colour in life: Dorsal area behind the head with five dark back patches clearly defined. (Anthoni 2007).

Colour in alcohol: Body with brownish blotches and darker vertical bands. Postorbital side of the head and isthmus with clear brownish dots. Dorsal fin with dark longitudinal bands and with light brownish dots. Anteroventral abdominal region light brown.

Distribution: Chironemus microlepis is endemic to Kermadec Island (New Zealand), Norfolk and Phillip Islands, and Lord Howe Island off Eastern Australia (Francis 1993) (Fig. 1), also Poor Knights Island off northwestern New Zealand (Anthoni 2007).

Comparisons: This species is morphologically very similar to C. bicornis, but differs from all Chironemus species in having more than 68 scales on the lateral line (Table 2).

\section{ACKNOWLedgments}

We thanks to the following persons and institutions for the loan of specimens and literature: Mark McGrouther (AMS), Sue Morrison (WAM), Tania Bardsley (MV), Clive D. Roberts, Chris Paulin, Robin McPhee (NMNZ), Christopher Burridge (TUAM), Karsten Hartel (MCZ), HJ Walker (SIO), Mark Westneat (FMNH), and Romain Causse (MNHN). Mr. Daniel Banchero draws fish figures.

This paper was mostly funded by FONDECYT grant $\mathrm{N}^{\circ}$ 1990172 to RMC and BDH, and partly by a National Geographic grant NGS 5257-96 to Mark Westneat and Brian Dyer.

\section{LITERATURE CITED}

Anthoni JD. 2007. Poor Knights marine reserve the common fishes of the Poor Knights. Seafriends Marine Conservation and Education Centre, New Zealand Islands. [on-line] $<$ http://www.seafriends.org.nz/issues/res/pk/fish.htm>

Bahamonde N \& G Pequeño. 1975. Peces de Chile. Lista sistemática. Publicación Ocasional, Museo Nacional de Historia Natural 21: 1-20.

Bauchot ML \& M Desoutter. 1989. Catalogue critique des types de poissons du Muséum National d'Histoire Naturelle. (Suite). Sous-ordre des Percoidei (Familles des Aplodactylidae, Apolectidae, Arripidae, Cepolidae, Cheilodactylidae, 
Chironemidae, Cirrhitidae, Echeneidae, Enoplosidae, Embiotocidae, Gerreidae, Lactariidae, Latrididae, Leiognathidae, Lobotidae, Malacanthidae, Menidae, Nandidae, Oplegnathidae, Owstoniidae, Pomatomidae et Rachycentridae. Bulletin of the Muséum National d'Histoire Naturelle. Section A 11(2) [Suppl]: 1-58.

Burridge CP, R Meléndez \& BS Dyer. 2006. Multiple origins of the Juan Fernández kelpfish fauna and evidence for frequent and unidirectional dispersal of cirrhitoid fishes across the South Pacific. Systematic Biology 55(4): 566-578.

Cuvier G \& A Valenciennes. 1829. Histoire naturelle des poissons. Tome troisième. Suite du Livre troisième. Des percoïdes à dorsale unique à sept rayons branchiaux et à dents en velours ou en cardes. Histoire Naturelle des Poissons 3: $1-500$.

De Buen F. 1959. Lampreas, tiburones, rayas y peces en la Estación de Biología Marina de Montemar, Chile. Revista de Biología Marina 9(1-3): 3-200.

Delfin FT. 1901. Ictiolojía chilena. Catálogo de los peces de Chile, 133 pp. Imprenta Gillet, Valparaíso.

Doak W. 1972. Fishes of the New Zealand region, 132 pp. Hodder and Stoughton, Auckland.

Dyer BS \& MW Westneat. 2010. Taxonomy and biogeography of the coastal fishes of Juan Fernández and Desventuradas Islands, Chile. Revista de Biología Marina y Oceanografía 45 (S1): 589-617.

Eschmeyer WM. 2009. The catalog of fishes. California Academy of Science. [on-line] <http://www.calacademy.org/ research/ichthyology/catalog/fishcatsearch.html>

Fowler HW. 1945. Fishes of Chile. Systematic Catalog. Apartado de la Revista Chilena de Historia Natural 45-47: 136, 1-171.

Fowler HW. 1951. Analysis of the fishes of Chile. Revista Chilena de Historia Natural 51-53: 263-326.

Francis MP. 1993. Checklist of the coastal fishes of Lord Howe, Norfolk, and Kermadec Islands, Southwest Pacific Ocean. Pacific Science 47(2): 136-170.

Gill TH. 1862. Sypnosis of the family cirrithoids. Proceedings of the Academy of Natural Sciences of Philadelphia 14: 102124.

Glover CJM. 1976. Vertebrate type-specimens in the South Australian Museum. I. Fishes. Records of the Australian Museum 17(7-12): 169-219.

Gomon MF, JCM Glover \& RH Kuiter. 1994. The fishes of Australia's South Coast. Flora and fauna of South Australia Handbooks Committee, 992 pp. State Printer, Adelaide.

Gomon MF, JCM Glover \& RH Kuiter. 2008. The fishes of Australia's South Coast. Flora and fauna of South Australia Handbooks Committee, 928 pp. State Printer, Adelaide.

Greenwood PH. 1995. A revised familial classification for certain cirrhitoid genera (Teleostei, Percoidei, Cirrhitoidea), with comments on the group's monophyly and taxonomic ranking. Bulletin of the Natural History Museum, London (Zoology) 61(1): 1-10.
Günther A. 1860. Catalogue of the fishes in the British Museum. Catalogue of the acanthopterygian fishes in the collection of the British Museum. Volumen 2. Squamipinnes, Cirrhitidae, Triglidae, Trachinidae, Sciaenidae, Polynemidae, Sphyraenidae, Trichiuridae, Scombridae, Carangidae, Xiphiidae, 548 pp. Taylor \& Francis, London.

Hector J. 1875. Notes on New Zealand ichthyology. Transactions of the New Zealand Institute, Zoology 7: 239250.

Herman JS, RY McGowan \& GN Swinney. 1990. Catalogue of the type specimens of recent vertebrates in the National Museum of Scotland. National Museum Scotland Information Series 4: 1-34.

Hubbs C \& KF Lagler. 1954. Fishes of the Great lake region, 213 pp. University of Michigan Press, Ann Arbor.

Kuiter RH. 1993. Coastal fishes of south-eastern Australia, 437 pp. University of Hawaii Press, Honolulu.

Last PR, EOG Scott \& FH Talbot. 1983. Fishes of Tasmania, 563 pp. Tasmanian Fisheries Development Authority, Hobart.

Leviton AE, RH Gibbs Jr, E Heal \& CE Dawson. 1985. Standards in herpetology and ichthyology. Part 1. Standard symbolic codes for institutional resource collections in herpetology and ichthyology. Copeia 1985: 802-832.

Mann FG. 1950. Peces de Chile. Clave de determinación de las especies importantes, $44 \mathrm{pp}$. Instituto de Investigaciones Veterinarias, Santiago.

Mann FG. 1954. Vida de los peces en aguas chilenas, 342 pp. Instituto de Investigaciones Veterinarias y Universidad de Chile, Santiago.

Meléndez R. 1990. Chironemid fishes from Juan Fernández Island and Desventuradas Island (Perciformes, Chironemidae). Revista de Biología Marina 25(2): 83-92.

Meléndez R \& C Villalba. 1992. Nuevos antedecedentes y registros sobre la ictiofauna del Archipiélago de Juan Fernández. Estudios Oceanológicos 11: 3-29.

Nelson JS. 2006. Fishes of the world, 601 pp. John Wiley and Sons, New York.

Ogilby JD. 1893. Edible fishes and crustaceans of New South Wales, 212 pp. Charles Potter, Government Printer, Sydney.

Paulin C, A Steward, C Roberts \& P McMillan. 1989. New Zealand fish. A complete guide. National Museum of New Zealand, Miscellaneous Series 19: 1-279.

Pequeño G. 1989. Peces de Chile. Lista sistemática revisada y comentada. Revista de Biología Marina 24(2): 1-132.

Pequeño G. 1997. Peces de Chile. Lista sistemática revisada y comentada: addendum. Revista de Biología Marina y Oceanografía 32(2): 77-94.

Pequeño G \& J Lamilla. 2000. The littoral fish assemblage of the Desventuradas Islands (Chile) has zoogeographical affinities with the Western Pacific. Global Ecology and Biogeography 9: 431-437. 
Pequeño G \& S Sáez. 2000. Los peces litorales del archipiélago de Juan Fernández (Chile): endemismo y relaciones ictiogeográficas. Investigaciones Marinas 28: 27-37.

Porter C. 1914. Sur quelques poissons comestibles du Chili et description d'une espèce nouvelle. Anales de la Sociedad Científica Argentina 77: 185-210.

Quijada B. 1913. Catálogo ilustrado i descriptivo de la colección de peces chilenos i extranjeros. Boletín Museo Nacional de Historia Natural, Chile 5(1): 1-139.

Regan CT. 1911. On the cirrhitiform percoids. Annals and Magazine of Natural History (Serie 8) 7: 259-262.

Rendahl H. 1921. The fishes of the Juan Fernandez Islands. In: Skottsberg C (ed). The Natural history of Juan Fernandez and Easter Island 3: 49-58. Almquist \& Wiksells, Uppsala.

Richardson J. 1850. Notices of Australian fish. Proceedings of the General Meetings for Scientific Business of the Zoological Society of London 1850(18): 58-77. [Also in Annals and Magazine of Natural History (Serie 2) 7: 273-292.]

Roughley TC. 1916. Fishes of Australia and their technology. Technological Museum, Sidney, Technical Education Series 21: 121-122.
Scott TD. 1954. Four new fishes from South Australia. Records of the South Australian Museum 11(2): 105-112.

Sepúlveda JI. 1987. Peces de las islas oceánicas chilenas. In: Castilla JC (ed). Islas oceánicas chilenas: Conocimiento científico y necesidades de investigaciones, pp: 225-245. Ediciones Universidad Católica de Chile, Santiago.

Steindachner F. 1898. Die Fische der Sammlung Plate. Zoologische Jahrbucher Supplement 1(4): 281-338, Pl. 1521. [Fauna Chilensis 1. Abhandlungen zur Kenntniss der Zoologie Chiles].

Taylor WR \& GC Van Dyke. 1985. Revised procedures for staining and clearing small fishes and other vertebrates for bone and cartilage study. Cybium 9(2): 107-119.

Waite ER. 1916. A list of the fishes of Norfolk Island, and indication of their range to Lord Howe Island, Kermadec Island, Australia, and New Zealand. Transactions of the Royal Society of South Australia 40: 452-458.

Weitzmann SH. 1974. Osteology and relationships of the Sternoptychidae, with a new classification of stomiatoid fishes. Bulletin of the American Museum of Natural History 153(3): 329-478.

Whitley GP. 1931. New names for Australian fishes. The Australian Zoologist 6: 310-334.

Recibido el 20 de julio de 2009 y aceptado el 29 de mayo de 2010 